\title{
Putting People in Jail, Putting People in Books: Author Characters in Agatha Christie and Dashiell Hammett
}

\begin{abstract}
The use of authors as fictional characters is a shared feature of two novels by authors who are often seen as diametrical opposites: Agatha Christie's Death in the Clouds (1935) and Dashiell Hammett's The Dain Curse (1928-1929). This article argues that the fictional authors have significant implications for our understanding of the two novels, not only because they serve as mediums for reflection on the detection genre and its conventions, but also, more importantly, because they initiate a complex interplay between conflicting forms of authority - a game of truth and fiction that threatens the authority of the detective protagonist and thereby calls into question the authoritative self-interpretation of the mystery plot as presented in the form of the detective's solution. The article presents a comparative analysis of two writers who are rarely studied together and may seem to have little in common, embodying as they do two distinctive styles of detective fiction. As the analysis shows, the close proximity of detectives and authors in both novels makes for an important and overlooked connection between them, bringing to light a set of shared epistemological ironies.
\end{abstract}

Keywords: Agatha Christie, authors as characters, Dashiell Hammett, detective fiction, metafiction

The career of crime fiction as an area of academic criticism has always been characterized by an ambiguous relationship to its object. On the one hand, scholars in popular fiction and cultural studies have done much to raise the status of crime fiction as a genre that is produced, bought, read, translated, and adapted on a colossal scale and is arguably the only literary genre with a truly global reach. On the other hand, critics have been reluctant to apply to this genre the same methods as those applied to what is sometimes referred to as literary fiction. In his seminal essay “The Typology of Detective Fiction,” Tzvetan Todorov (1977) argues, for example, that individual instances of detective fiction are ultimately nothing more than embodiments of a stable structure with only three major variants, which he conceptualizes as the whodunit, the thriller, and the suspense novel; accordingly, there is no particular need for a critical approach that uncovers the individuality of the singular literary text. Much later, in 2004, Ken Gelder argues, 
drawing on Pierre Bourdieu's (1993) dualist account of the "literary field," that a categorical divide separates "popular fiction" from "Literature," and that the former is generally seen not to warrant the detailed scrutiny devoted to the latter (Gelder 2004, 35-39). What has emerged as a result of these and related contributions is an epistemic regime - one that allows for many exceptions - that determines which critical activities can and cannot be brought to bear on crime fiction texts. Under this regime, crime fiction can be explored in terms of genre and genre evolution; analysed contextually from the point of view of the publishing industry or the social, cultural, or political environment; or mapped and charted using the broad, sweeping perspective of the fan, the historical surveyor, or the taxonomist. However, unlike "Literature," crime fiction texts are not commonly subjected to detailed textual analysis with a view to establishing their individual - as opposed to strictly generic - ways of generating narrative and meaning. ${ }^{1}$

The following comparative discussion of Agatha Christie and Dashiell Hammett forms part of a larger, collaborative research project, "Crime Fiction on the Move," which challenges this view (Gulddal, King, and Rolls 2019). Against the notion that crime fiction is formula-bound and static, we want to highlight the formula-bending dynamism of crime fiction and the ways in which the genre evolves as a result of constant self-critical experimentation. Whereas the field of literary studies has in recent years veered away from close textual analysis in favour of new forms of "distant reading" (Moretti 2013), we assert that distant reading was always the default mode of crime fiction studies, and that genuine innovation in this area therefore necessitates the opposite movement, from distant to close critical reading. ${ }^{2}$ Contesting the idea of an ontological divide between popular and literary fiction, we work on the assumption that lit-

1 To get a sense of this epistemic divide, one only has to take stock of the many books devoted to the history and evolution of crime fiction as a genre while at the same time looking at the relatively few titles devoted to the critical assessment of individual crime fiction authors or novels. It is striking to note, for example, how relatively little academic criticism is available on Agatha Christie, who, according to the Agatha Christie Ltd website (n.d.), is "the best-selling author of all time," and, further, to see a book published as recently as 2016 lay claim to being "the first major scholarly collection of essays on Christie in English" (Bernthal 2016, 1). The French literary critic Pierre Bayard's detective criticism trilogy $(2000,2002,2008)$ represents an ambitious, although perhaps also somewhat extreme, attempt to apply close analysis strategies to crime fiction classics. Alistair Rolls and I have engaged critically with Pierre Bayard's "detective criticism” in two complementary journal articles (Gulddal and Rolls 2015; Rolls and Gulddal 2016).

2 More specifically, innovation in this area seems to require the combination of close-reading practice with a global outlook on the genre (see Gulddal, King and Rolls 2019, 1-24). For an example of a close reading of Agatha Christie inspired by psychoanalysis, see Rolls (2015). 
erature is a highly diverse field of variously interrelated textual practices, and that a neat segregation of this field using criteria of popularity or genre blinds us to the hybrid forms that make up a considerable part of what we refer to as literature.

It is this broad research agenda that provides the framework for this paper's comparative discussion of Agatha Christie's Death in the Clouds (first published 1935) and Dashiell Hammett's The Dain Curse (first published 1928-1929). My specific entry point is a type of self-reflexivity characteristic of detective fiction, centred on the use of authors as fictional characters and the complex relationship between such author characters, the detective protagonists, and the real authors. This triangular relationship looms large in the history of crime fiction, arguably appearing for the first time in Edgar Allan Poe's detective stories in the form the detective-and-sidekick structure that would later become a commonplace of the genre. However, as I argue in the following pages, the interpretive implications of this relationship, which also manifests itself in a range of other forms, have not been fully appreciated. In Christie and Hammett, the appearance of author characters seems to initiate a complex interplay of conflicting forms of authority - a game of truth and fiction which threatens the authority of the detective protagonist and thereby calls into question the authoritative self-interpretation of the mystery plot as presented in the form of the detective's concluding solution. What follows, then, is a comparative analysis of two authors who are rarely studied together and may seem to have little in common, embodying as they do two distinctive styles of detective fiction. However, as my analysis will show, the close association of the detective and the author in the two novels makes for an important, and overlooked, connection between them, bringing to light a set of shared epistemological ironies.

Agatha Christie is sometimes seen as the queen of "formula fiction" (Cawelti 1976, 111). The widespread view implied by this characterization is that two-dimensional characters and contrived plots abound in Christie's works, and that they - by adhering closely to proven patterns and conventions - represent the opposite of "real" literature, which is wedded instead to an ideal of genre-transcending originality. While there is no denying that Christie's detective fiction contains formulaic elements, there is reason to challenge this view. The noted crime fiction writer P. D. James talks about the "extraordinary variety of books and writers which this so-called formula has been able to accommodate, and how many authors have found the constraints and conventions of detective fiction liberating rather than inhibiting of their creative imagination" $(2009,16)$. This 
statement applies particularly well to Christie's works. ${ }^{3}$ Far from simply rehashing existing genre conventions, Christie can usefully be read as an experimental writer who constantly challenges the rules and constraints of the genre, and in this sense she has more in common with her modernist contemporaries than she normally gets credit for (see Birns and Birns 2010). Her experimental streak manifests itself most clearly in a constant search for new ways of both committing and investigating murder; often, this involves clean breaks with convention as well as challenging the idea that authors of detective fiction should "play fair" with their readers. Yet it also comes to the fore in her constant play with narrative voice, with reader expectations, and with the detective's authority, which is often challenged by means of subtle, and sometimes not-so-subtle, ironies (Gulddal 2016, 18-20).

Christie's 1935 novel Death in the Clouds includes among its cast an author of whodunit novels, Mr Clancy. This person is thrilled on learning that the murder that took place on his flight from Paris to Croydon was seemingly committed using an indigenous South American blowpipe and a dart soaked with the poison of an exotic snake. The reason for his "blissful excitement" is that this murder weapon clearly references detective fiction conventions; the killer in Arthur Conan Doyle's The Sign of Four also uses poison darts, and Clancy himself claims to have used a very similar device "both in book and short story form" (Christie 2003, 485). In other words, the murder of Madame Giselle appears to be a case of reality mirroring, and perhaps even outdoing, detective fiction: “'As I say, most extraordinary. I am myself a writer of detective stories, but actually to meet, in real life -'. Words failed him" (391).

Determined not to be upstaged, Mr Clancy sets to work writing a detective novel based on the events of the Croydon flight, featuring his banana-eating and nail-biting private investigator, Wilbraham Rice. His outline for this novel, the working title of which is The Air Mail Mystery, is a witty parody of the whodunit format as well as a bit of self-deprecating fun on the part of Agatha Christie herself. It uses the setting and characters of the real-life murder mystery, yet introduces its own suitably contrived solution involving a female murderer who is not only a contortionist and a master of disguise, but also a parachute jumper, a snake charmer, and a chemist with ready access to the "newest gas" (Christie 2003, 486). "You can't write anything too sensational," Clancy states in defence of this plot. "After all, you don't want a detective story to be like real life? Look at the things in the papers - dull as ditchwater" (487).

3 It is worth mentioning here that P. D. James, despite her emphasis on the productive and liberating aspects of formula writing, regards Christie as a cunning but conventional writer whose greatest strength was that "she never overstepped the limits of her talent" $(2009,4)$. 
However, Mr Clancy's character and his remarks on the poetics of the detective story are not just a witty interlude, but also generate a string of self-reflexive ironies that are significant in terms of our understanding of this novel. In the first instance, these ironies concern the relationship between fiction and reality. It can reasonably be assumed that Christie introduces Mr Clancy so as to establish an opposition between a sensationalist type of detective fiction and the allegedly more serious type that she herself represents - in other words, that Clancy fulfils the same narrative function as the numerous derogatory references to detective fiction that are scattered across Christie's novels, namely that of assuring readers that the story they are reading is in fact more real and less fanciful than the standard detective writing of the day. Yet, by situating the novel's murder plot at the halfway point between the detective fiction conventions on which it draws and the (fictional) detective fiction it inspires, Christie arguably achieves the exact opposite. If anything, this curious framing suggests that the novel's own murder plot is simply one in a sequence of fictions, and thereby foregrounds its artificiality rather than its realism. This irony is not lost on Mr Clancy, who at one point takes to calling Poirot "Watson," casting himself in the role of Sherlock Holmes. Clancy is suggesting that Poirot serves as his "idiot friend." However, in a wider sense, the implication is that the roles of the detective and the detective fiction writer are interchangeable, and even that their methods are similar: both are sense-making operations that transform a mass of heterogeneous and sometimes conflicting information into a meaningful narrative.

The novel returns to this radical point at the very end, in the context of Poirot's solution. The revelation in this case does not occur in a great drawing-room scene, but is an intimate affair attended only by Poirot himself, Inspector Japp, the murderer (whose name is Norman Gale), and Mr Clancy. While the first three invitees are clearly required to be present, forming as they do the familiar triad of policeman, amateur detective, and culprit, there is no compelling narrative reason why Clancy needs to be there; he is clearly the odd one out, having nothing to do with the murder. Poirot may have invited him due to a desire to settle the score with this somewhat arrogant writer and at the same time establish once and for all the difference between the detective and the author of detective fiction. Yet, even though Clancy appears to admit defeat, referring to Poirot's final revelation as "absolutely the most thrilling experience of my life. You have been wonderful!” (Christie 2003, 550), the set-up once again casts doubt on exactly what it sets out to prove. The neat separation of fiction and reality collapses when an indignant Norman Gale, confronted with Poirot's accusation, suggests that the detective "adopt Mr Clancy's profession" (548), that is, becomes a writer. Moreover, it is never made clear what exactly Clancy admires in Poirot. Is it his skills as a detective, or it is rather his talent for storytelling - his genius for turning jumbled bits of informa- 
tion into a strong and coherent plot, eliminating all competing possibilities in the process?

Just as there is no narrative reason why Mr Clancy should be present in the final scene, there is no narrative reason why he should feature in the novel at all. In terms of the murder mystery itself, he is eminently replaceable. The fact that he is present and does feature, and that he throughout the novel hovers in close proximity to Poirot, suggests that his presence is required to make a point of a more general nature. A type of self-referentiality, yes, but perhaps also a broader questioning of some of the pillars of the whodunit format, particularly the distinctions between the rational and the imaginative, and the critical and the creative, and the definition of truth in terms of either correspondence with facts or the coherence of a narrative. We cannot be absolutely sure that Christie had any awareness of these ironies; but, as someone who was herself constantly moving between the roles of Poirot and Clancy, being, like Clancy, a real author and an imagined detective, she may well have been more aware than she lets on, and more aware than the dismissive view of detective fiction as simple and formulaic can accommodate. It is certainly true that Christie often treats her detective protagonists with continual irony, intimating in this way that detective work is not simply about order and method, as Poirot would have it, but also, like detective writing, about crafting persuasive and coherent narratives. ${ }^{4}$

A similar use of the author as a fictional character, and one that generates similar ironies, can be found in Dashiell Hammett's The Dain Curse (first published 1928-1929). A pulp shocker cobbled together from short stories to capitalize on the success of Red Harvest, this novel is often regarded as Hammett's least successful. Yet, although The Dain Curse certainly has a sensationalist feel, it cannot be dismissed out of hand as incoherent. It does cohere, but its plot is not one that builds towards a fully transparent and authoritative ending. Quite on the contrary, Hammett's plot seems to imply a progressive dismantling of the detective format itself. Accordingly, it describes a movement not towards clarity, but towards increasing levels of uncertainty.

4 For further discussion of this question, see Gulddal (2016, 16-18). Ariadne Oliver, the best-selling detective author who appears in seven novels, is the most sustained and elaborate example of this use of authors as fictional characters. For an analysis that draws in part on Bayard, see Grauby (2016). 
Just as in Christie's Death in the Clouds, this dismantling of genre conventions and concurrent production of uncertainty is strongly associated with an author, the detective protagonist and narrator's friend, Owen Fitzstephan. The narrative importance of this author character is underlined by the fact that he appears at the end of each of the novel's three parts and is eventually given a key role in the overall plot.

Fitzstephan is introduced early in the novel in a way that openly and insistently suggests that the apparent opposition between the creative writer and the critical detective obscures a more fundamental similarity between the two professions. The detective and the author met each other for the first time five years before the main storyline begins, when both were in New York investigating, with different intentions and from the point of view of their different professions, a criminal gang of fake spiritual mediums. Since they were already "plowing the same field" (Hammett 1999, 206), they decided to collaborate. This similarity between their respective investigative practices is expanded upon by Fitzstephan when they are reacquainted in San Francisco in the novel's present:

\footnotetext{
“Are you - who make your living snooping - sneering at my curiosity about people and my attempts to satisfy it?”

"We're different," I said. "I do mine with the object of putting people in jail, and I get paid for it, though not as much as I should."

"That's not different," he said. "I do mine with the object of putting people in books, and I get paid for it, though not as much as I should.” (Hammett 1999, 210)
}

The set-up here is very similar to what we found in Christie. In Death in the Clouds, the close association of Poirot and Mr Clancy suggested that the roles of detective and author have a common basis in storytelling. In The Dain Curse, there is a similar logic at work, which extends far beyond Fitzstephan's glib remark. After their initial meeting, the detective and the author meet again in the final chapter of each of the novel's first two sections. Their conversations, each of which conclude a relatively stand-alone part of the novel, clearly recall not just the standard revelation scene and the end of the conventional detective story, but also the classic relationship between the detective and his writer friend - the Holmes/Watson connection that Mr Clancy refers to explicitly in Christie's novel. Yet Hammett cites these conventions only to dismantle them. The conversations fail to produce clarity, and foreground instead the narrative aspects of the proposed solutions, thereby presenting the act of detection as a search for a story that convincingly accounts for the facts of the case - a coherence theory of truth that allows for the possibility that what really happened was different. In the first conversation, the detective's attempt to put the pieces together results in a highly disjointed narrative shot through with hypotheticals and what Fitzstephan calls 
"two buts and an if" (Hammett 1999, 248). If the aim is to produce clarity, the conversation is a complete failure, and the case is accordingly filed by the Continental Detective Agency as “Discontinued” (Hammett 1999, 249; italics in original) rather than solved or concluded. The second conversation is even more explicit. The detective repeatedly interrupts his narrative, declaring three times in succession that the presumed solution is nonsensical and that the murder could have been committed by "anybody else." As he says to Fitzstephan: "I hope you're not trying to keep this nonsense straight in your mind. You know damned well all this didn't happen" (284).

The third conversation, which takes places at the end of the novel, is arguably Hammett's attempt to provide clarity and tie together the novel's three very different and relatively independent parts. Certain facts point in that direction, above all the detective's proposed solution. At this point in the narrative, Fitzstephan has suffered very extensive injuries in a bomb explosion, and it is not clear whether or not he will recover. The detective visits him in hospital and, in an unexpected turn of events, identifies him as the mastermind behind most of the novel's many murders, going all the way back to the first part. In presenting this solution, the detective is explicit about the narrative function that Fitzstephan is called upon to fulfil, namely that of providing retrospective clarity and coherence to an otherwise highly fragmented plot. As Fitzstephan himself remarks, he is precisely the "one person who has that sort of mind, and whose connection with each episode can be traced" (Hammett 1999, 375).

Yet this sudden certainty, epitomized by the detective's concluding retelling of the story in what is alleged to be its true logical order, leaves several key questions unanswered. First of all, the detective's narrative is based almost exclusively on Fitzstephan's own confession, and only a few facts are corroborated by witnesses. However, this confession is presented as nothing more than a legal defence strategy designed to support an insanity plea; the author deliberately confesses to as many crimes as he possibly can "on the theory that nobody but a lunatic could have committed so many" (Hammett 1999, 376). Second, it is important to note that the author and the detective have an interest in common. Just as Fitzstephan has a clear interest in lying and exaggerating, the detective has clear interest in believing him. Fitzstephan uses his tall tales to secure an insanity verdict. The detective narrator uses these tall tales to provide investigative and narrative closure. Fitzstephan's story is precisely the best, and possibly the only, way of bringing the case and the novel itself to a satisfying end.

The point is, however, that this solution is not satisfying; it might be coherent, or reasonably coherent, but we have no way of knowing whether or not it is true in the sense of capturing what really happened. Even more so than in Death in the Clouds, the allegedly authoritative solutions produce uncertainties and ironies 
that are never resolved, and cannot be resolved due to the unsettling interactions between the detective and the author. ${ }^{5}$

Christie and Hammett are very different writers both in terms of style and general approach to the detective genre. Yet the close association of the detective and author characters in both Death in the Clouds and The Dain Curse brings to light a commonality that is not normally acknowledged. In both novels, this association is used as a means of subtly challenging the authority of the detective and thereby also calling into question the seemingly incontestable solution provided the end as a stock element of the detective genre.

By doing so, Christie's and Hammett's novels seem to highlight an aspect of the detective novel that has been analysed in detail by the French literary critic Pierre Bayard. In Bayard's view, the whodunit-type detective novel is characterized by the presence of multiple virtual storylines that readers are invited to actualize and complete as they read. While the detective ultimately privileges one of these possibilities, this seemingly authoritative solution is never able to eliminate fully all the virtual narratives that make up the bulk of the book, and it is therefore entirely possible, Bayard argues, that one or more will remain intact even at the end of the book as a potential alternative to the detective's version of events (2000, 67-68). By associating the detective's search for truth with the author's search for narrative coherence, Christie's and Hammett's novels seem to make a similar point, namely that the authority of the detective is ultimately a matter of narrative prowess, of telling stories that make sense of events, and that these stories could also have been told otherwise - as indeed they are in both novels, several times over.

A simpler way of making this point is to say that in detective fiction the mystery that reigns for the majority of the story is at odds with the clarity that is established at the end. It is sometimes argued - most recently by Luc Boltanski (2014, 1-39) - that the detective genre was traditionally tasked with assuring readers of the orderliness and cohesiveness of their reality. In this view, detective fiction is an antidote to the relativity that forms the epistemic foundation of modernity. Yet, as I have shown in this essay, the figure of the author in Death in the Clouds and The Dain Curse reminds readers that the semblance of order and transparency that these novels project is crafted out of uncertainties similar to those addressed by modernist authors of the same period. The author characters - be they $\mathrm{Mr}$

5 For a more detailed analysis of Hammett's novel, see Gulddal 2019. 
Clancy or Owen Fitzstephan - allow these uncertainties to surface in the novels, highlighting the narrative contrivance of the detective's solution and suggesting that the process of detection is uncannily similar to storytelling.

\section{Works cited}

Agatha Christie Ltd. “The Home of Agatha Christie.” n.d. www.agathachristie.com (26 November 2018).

Bayard, Pierre. Who Killed Roger Ackroyd? The Mystery Behind the Agatha Christie Mystery. Trans. Carol Cosman. New York: The New Press, 2000.

Bayard, Pierre. Enquête sur Hamlet. Paris: Minuit, 2002.

Bayard, Pierre. L'Affaire du Chien des Baskerville. Paris: Éditions de Minuit, 2008.

Bernthal. J. C. "Introduction: Mystery and Legacy." Ageless Agatha Christie: Essays on the Mysteries and the Legacy. Ed. Bernthal. Jefferson: McFarland, 2016. 3-10.

Birns, Nicholas, and Margaret Boe Birns. "Agatha Christie: Modern and Modernist." The Cunning Craft: Original Essays on Detective Fiction and Contemporary Literary Theory. Eds. Roland G. Walker and June M. Frazer. Macomb: Western Illinois University Press, 2010. 120-134.

Boltanski, Luc. Mysteries and Conspiracies: Detective Stories, Spy Novels and the Making of Modern Societies. Cambridge: Polity Press, 2014.

Bourdieu, Pierre. "The Field of Cultural Production, or The Economic World Reversed." The Field of Cultural Production. By Bourdieu. New York: Columbia University Press, 1993. 29-73.

Cawelti, John G. Adventure, Mystery, and Romance: Formula Stories as Art and Popular Culture. Chicago and London: The University of Chicago Press, 1976.

Christie, Agatha. Death in the Clouds. 1935. Poirot: The French Collection. By Christie. London: HarperCollins, 2003. 375-552.

Gelder, Ken. Popular Fiction: The Logics and Practices of a Literary Field. Milton Park, Abingdon: Routledge, 2004.

Grauby, Françoise. “'This Isn’t a Detective Story, Mrs Oliver’: The Case of the Fictitious Author.” Clues: Journal of Detection 34.1 (2016): 116-125.

Gulddal, Jesper. “'Beautiful Shining Order’: Detective Authority in Agatha Christie’s Murder on the Orient Express.” Clues: Journal of Detection 34.1 (2016): 11-21.

Gulddal, Jesper. "Foggy Muddle. Narrative, Contingency and Genre Mobility in Dashiell Hammett's The Dain Curse." Criminal Moves. Modes of Mobility in Crime Fiction. Eds. Gulddal, Stewart King, and Alistair Rolls. Liverpool: Liverpool University Press, 2019. 113-128.

Gulddal, Jesper, and Alistair Rolls. "Mobile Criticism: Pierre Bayard's Irreverent Hermeneutics.” Australian Journal of French Studies 52.1 (2015): 37-52.

Gulddal, Jesper, Stewart King, and Alistair Rolls. "Criminal Moves. Towards a Theory of Crime Fiction Mobility”. Criminal Moves. Modes of Mobility in Crime Fiction. Eds. Gulddal, King, and Rolls. Liverpool: Liverpool University Press, 2019.1-24.

Gulddal, Jesper, Stewart King, and Alistair Rolls, eds. Criminal Moves: Modes of Mobility in Detective Fiction. Liverpool: Liverpool University Press, 2019. 
Hammett, Dashiell. The Dain Curse. 1928-1929. Complete Novels. By Hammett. New York:

Library of America, 1999. 193-386.

James, P. D. Talking about Detective Fiction. Oxford: Bodleian Library, 2009.

Moretti, Franco. Distant Reading. London: Verso, 2013.

Rolls, Alistair. "An Ankle Queerly Turned, or The Fetishised Bodies in Agatha Christie's The Body in the Library." Textual Practice 29.5 (2015): 825-844.

Rolls, Alistair, and Jesper Gulddal. "Pierre Bayard and the Ironies of Detective Criticism: From Text Back to Work." Comparative Literature Studies 53.1 (2016): 150-169.

Todorov, Tzvetan. “The Typology of Detective Fiction.” The Poetics of Prose. By Todorov. Trans. Richard Howard. Oxford: Blackwell, 1977. 42-52.

Jesper Gulddal is associate professor in Literary Studies at the University of Newcastle, Australia. He has published books and articles on the literary history of anti-Americanism, the nexus of mobility and movement control in the modern novel, and crime fiction. Recent essays have appeared in journals such as New Literary History, German Life and Letters, Nineteenth-Century Contexts, Textual Practice, Comparative Literature Studies, and Comparative Literature. 
